\title{
Improvement of Efficiency in CdS Quantum Dots Sensitized Solar Cells
}

\author{
S. WAGeh ${ }^{a, b, c}$, A.A. Al-Ghamdi ${ }^{a, c}$, M. Soylu ${ }^{d, *}$, Y. Al-Turki ${ }^{e}$, W. El Shirbeeny ${ }^{a, c}$ \\ AND F. YAKUPHANOGLU ${ }^{a, f, c}$ \\ ${ }^{a}$ Department of Physics, Faculty of Science, King Abdulaziz University, Jeddah 21589, Saudi Arabia \\ ${ }^{b}$ Physics and Engineering Mathematics Department, Faculty of Electronic Engineering, Menoufia University \\ Menouf 32952, Egypt \\ ${ }^{c}$ Advances in Composites, Synthesis and Applications Group, King Abdulaziz University, Jeddah, Saudia Arabia \\ ${ }^{d}$ Department of Physics, Faculty of Sciences and Arts, Bingol University, Bingol, Turkey \\ ${ }^{e}$ Department of Electrical Engineering, Faculty of Engineering, King Abdulaziz University, Jeddah, Saudia Arabia \\ ${ }^{f}$ Department of Physics, Faculty of Science, Firat University, Elazig 23169, Turkey
}

(Received July 1, 2013; in final form August 5, 2013)

CdS quantum dots were coated on $\mathrm{TiO}_{2}$ layer by successive ionic layer adsorption and reaction method. An efficient photovoltaic energy conversion and significant quantum-size effect were observed. The magnitude of the short-circuit photocurrent density $J_{\mathrm{SC}}$ was found to be approximately $6.01 \mathrm{~mA} / \mathrm{cm}^{2}$ for graphene oxide-incorporated $\mathrm{CdS} / \mathrm{TiO}_{2}$ solar cell, while the $J_{\mathrm{SC}}$ of only CdS-sensitized solar cells was lower than $4.40 \mathrm{~mA} / \mathrm{cm}^{2}$. The efficiency of the $\mathrm{CdS} / \mathrm{TiO}_{2}$ solar cell with a graphene oxide layer containing CdS QDs was $60 \%$ higher than that of the $\mathrm{CdS} / \mathrm{TiO}_{2}$ solar cell. The cell efficiency was remarkably improved with the graphene oxide-incorporation. The carrier recombination of the QDs sensitized solar cells based on CdS-coated $\mathrm{TiO}_{2}$ was significantly suppressed due to photogenerated charge carrier transports resulting from the presence of graphene oxide.

DOI: $10.12693 /$ APhysPolA.124.750

PACS: 85.35.Be, 88.40.hj, 72.80.Vp, 68.47.Gh

\section{Introduction}

Due to its large band gap (anatase $3.2 \mathrm{eV}$, rutile $3.0 \mathrm{eV}$ ), $\mathrm{TiO}_{2}$ has a disadvantage in its use as an ideal photoelectrode. There are many attempts to reduce the band gap of $\mathrm{TiO}_{2}[1-5]$. However, $\mathrm{TiO}_{2}$ has potential application due to its excellent photocatalytic activity and long-term chemical stability $[6-9]$. $\mathrm{TiO}_{2}$ is the critical component of the dye-sensitized solar cell (SC) [10]. Sambur et al. [11] reported that an improvement of the collection of photocurrents with quantum yields greater than one electron per photon in a photoelectrochemical system, composed of $\mathrm{PbS}$ nanocrystals chemically bound to $\mathrm{TiO}_{2}$ single crystals.

Quantum dots (QDs) sensitized solar cells are the new production solar cells that contain photovoltaic technologies having multiple layers [12]. QDs are used as the absorbing photovoltaic material and their energy gaps can be adjusted by changing the QD size. These properties are the potential benefits of QDs. The application of $\mathrm{PbS}$ as a sensitizer in SCs has been reported by many researchers [13-17]. PbS sensitizer in QDSCs is faced with problems such as poor stability and high recombination which lead to low performance. To overcome these problems, the direct growth of a CdS coating layer on previously deposited $\mathrm{PbS}$ is beneficial compared with that sensitized by only $\mathrm{PbS}$ nanoparticles [18]. Cadmium sulphide (CdS) belonging to the II-VI group has indicated

*corresponding author; e-mail: soylum74@yahoo.com much promise as an effective QD sensitizer due to the suitability of its band gap $(2.4 \mathrm{eV})$ to $\mathrm{TiO}_{2}$ [19]. Mali et al. [20] have loaded CdS nanoparticles on titanium oxide nanocorals (TNC) using successive ionic layer adsorption and reaction (SILAR) method. They obtained a power conversion efficiency of $0.72 \%$ for $\mathrm{TiO}_{2}-\mathrm{CdS}$ electrodes. This indicates that a good passivation layer minimizes the recombination of the charge carriers in the solar cells.

Graphene is an attracting material, which has optical transmittance of $97.7 \%$ [21]. It is one of the excellent transport materials due to its low electron-phonon scattering and high carrier mobility. Graphene oxide (GO) was reported replacing PEDOT:PSS as a layer, which provides hole transporting in polymer solar cells $[22,23]$. Photocurrent density measurements in NiO-based dye sensitized solar cells indicate that recombination of photogenerated charges depends on the presence of graphene [24]. Liu et al. [25] reported a single-layer graphene as the top electrodes of semitransparent organic solar cells. They found a maximum efficiency of about $1.4 \%$, corresponding to a thickness of about $410 \mathrm{~nm}$.

In the present paper, we studied the graphene oxide effects on the efficiency of CdS quantum dots sensitized solar cell. $\mathrm{TiO}_{2}$ was fabricated using the sol-gel method, which is a simple and fast way to obtain the oxide layer. The graphene oxide powder was distributed onto the surface of CdS coated $\mathrm{TiO}_{2}$ film. Overall power conversion efficiency of quantum dots sensitized solar cell based on CdS coated $\mathrm{TiO}_{2}$ is much higher than those of only CdS-sensitized solar cell. 


\section{Experimental details}

$\mathrm{TiO}_{2}$ nanopowders were prepared by sol-gel method. The used precursors are titanium tetraisopropoxide (TTIP), distilled water, ethyl alcohol (EtOH) and hydrochloric acid $(\mathrm{HCl}) . \quad \mathrm{TiO}_{2}$ powders were prepared for the various volume ratios. The volume ratio of TTIP:EtOH: $\mathrm{H}_{2} \mathrm{O}: \mathrm{HCl}$ was 1:15:60:0.2. Titanium tetraisopropoxide was dissolved in water, alcohol and acid solution under stirring for $48 \mathrm{~h}$ at room temperature. The prepared solution was precipitated and the obtained powders were filtered and dried at $50^{\circ} \mathrm{C}$ for $2 \mathrm{~h}$ and annealed at $400{ }^{\circ} \mathrm{C}$ for $3 \mathrm{~h}$. For preparation $\mathrm{TiO}_{2}$ paste, $1 \mathrm{~g}$ of $\mathrm{TiO}_{2}$ powders in $1.8 \mathrm{ml}$ of DI water, $30 \mu \mathrm{l}$ of acetylacetone and $30 \mu \mathrm{l}$ of terpineol was milled for $1 \mathrm{~h}$ and then the stirring was continued for $8 \mathrm{~h}$. The tin doped fluorine (FTO substrate) (10 $\Omega$ /square) coated on glass substrate was purchased from Sigma-Aldrich company. This substrate was used as ohmic contact electrode. Before $\mathrm{TiO}_{2}$ paste was coated on FTO substrate, the FTO substrate was cleaned ultrasonically in methanol, acetone and DI water for 5 min. The $\mathrm{TiO}_{2}$ paste was deposited on a FTO glass by doctor blade method. The prepared $\mathrm{TiO}_{2}$ layer was sintered at $500^{\circ} \mathrm{C}$ for $1 \mathrm{~h}$ in air. The CdS quantum dots were deposited on $\mathrm{TiO}_{2}$ layer by SILAR method. The solutions of $0.5 \mathrm{M} \mathrm{Cd}\left(\mathrm{NO}_{3}\right)_{2}$ in ethanol and $0.5 \mathrm{M} \mathrm{Na}_{2} \mathrm{~S}$ in methanol were prepared. The $\mathrm{TiO}_{2}$ layer was dipped into $0.5 \mathrm{M} \mathrm{Cd}\left(\mathrm{NO}_{3}\right)_{2}$ solution for $30 \mathrm{~s}$ and rinsed with ethanol and then, dipped into $0.5 \mathrm{M} \mathrm{Na}_{2} \mathrm{~S}$ for $30 \mathrm{~s}$ and rinsed with methanol. These dipping procedures are considered as one cycle. The coating procedure was repeated for 5 times $[26,27]$. The polysulfide (redox couple, $\mathrm{S}^{2-} / \mathrm{S}_{n}^{2-}$ ) electrolyte was prepared using $0.5 \mathrm{M}$ $\mathrm{Na}_{2} \mathrm{~S}, 2 \mathrm{M} \mathrm{S}$, and $0.2 \mathrm{M} \mathrm{KCl}$. Graphene oxide (GO) was prepared by the modified Hummers method [28]. To synthesize GO, $2 \mathrm{~g}$ graphite was dissolved in $250 \mathrm{ml} \mathrm{H}_{2} \mathrm{SO}_{4}$ in ice bath and $8 \mathrm{~g} \mathrm{KMnO} 4$ and $1 \mathrm{~g} \mathrm{NaNO}_{3}$ were added to this solution while stirring. The solution was transferred to water bath at $30^{\circ} \mathrm{C}$. After $20 \mathrm{~min}$ stirring, $250 \mathrm{ml}$ de-ionized water was slowly added and temperature was raised to $98^{\circ} \mathrm{C}$ and the solution was kept at this temperature for $30 \mathrm{~min}$. The reaction was terminated by adding de-ionized water $(300 \mathrm{ml})$ and followed by the addition of $40 \mathrm{ml}$ of $35 \% \mathrm{H}_{2} \mathrm{O}_{2}$ solution. The color of the solution was changed to brilliant yellow. The obtained powder was washed and filtered and dried at $50{ }^{\circ} \mathrm{C}$ for 2 days. To improve the efficiency of solar cell, GO powder was distributed onto the surface of $\mathrm{CdS}$ coated $\mathrm{TiO}_{2}$ layer and the electrical characteristics of the prepared solar cell were measured using a KEITHLEY 4200 semiconductor characterization system.

\section{Results and discussion}

\subsection{Photovoltaic performance of $C d S$ quantum dots solar cells}

The photovoltaic performance of the solar cell was examined under various illuminations. For the $\mathrm{CdS} / \mathrm{TiO}_{2}$ nanostructured solar cell exposed to solar flux, the following process occurs [29]:

$$
\begin{aligned}
& \mathrm{CdS} \stackrel{\mathrm{h} \nu}{\longrightarrow} \mathrm{CdS}\left(\mathrm{h}^{+}+\mathrm{e}\right), \\
& \mathrm{CdS}\left(\mathrm{h}^{+}+\mathrm{e}^{-}\right)+\mathrm{TiO}_{2} \rightarrow \mathrm{CdS}(\mathrm{h})+\mathrm{TiO}_{2}(\mathrm{e}), \\
& \mathrm{CdS}(\mathrm{h})+\mathrm{S}^{2-} \rightarrow \mathrm{CdS}+\mathrm{S}_{n}^{2-},
\end{aligned}
$$

where $\mathrm{S}^{2-} / \mathrm{S}_{n}^{2-}$ is the redox couple for $\mathrm{CdS} / \mathrm{TO}_{2}$ sample obtained from the polysulfide electrolyte, which is prepared using $\mathrm{Na}_{2} \mathrm{~S}, \mathrm{~S}$, and $\mathrm{KCl}$. The current density dependence of illumination intensity is shown in Fig. 1. As seen in Fig. 1, the current density increases with increasing light illumination intensity. Also, one can observe that the incorporation of graphene-oxide in $\mathrm{CdS} / \mathrm{TiO}_{2}$ solar cell increased the photocurrent density by $37.5 \%$ to reach $5.82 \mathrm{~mA} / \mathrm{cm}^{2}$ under $100 \mathrm{~mW} / \mathrm{cm}^{2}$.

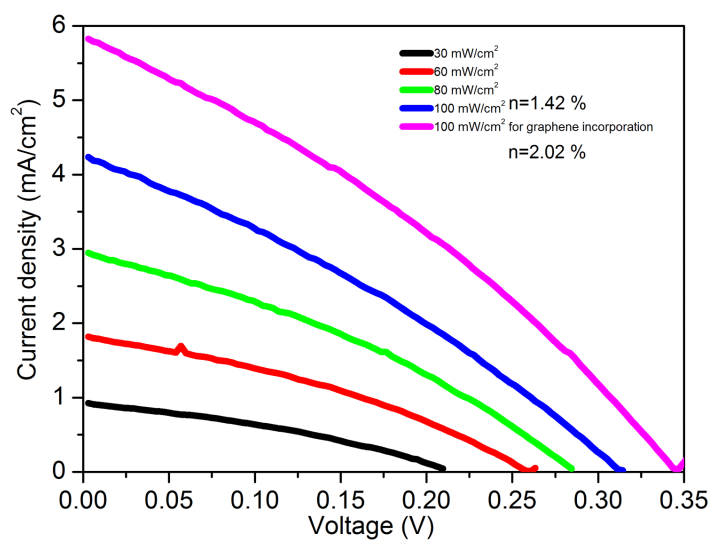

Fig. 1. Photocurrent density-voltage characteristic for $\mathrm{CdS} / \mathrm{TiO}_{2}$ solar cells with the CdS SILAR cycles.

Figure 2 shows the photosensitivity of the solar cell based on $\mathrm{CdS}$ coated $\mathrm{TiO}_{2}$ with variation of short-circuit photocurrent density $\left(J_{\mathrm{SC}}\right)$ vs. the incident irradiation power $(P)$. As seen in Fig. 2, the $J_{\mathrm{SC}}$ can be analyzed by a power law function, i.e. $J_{\mathrm{SC}} \propto P^{m}$ [30]. The value of $m$, which depends on the charge recombination, was found to be $1.20 \pm 0.2$. This value of $m$ indicates the presence of lower density of trapping centers and, therefore, a perfect material with a more regular structure [31-33]. The obtained $m$ value higher than unity implies that the photoconductivity of the solar cell is controlled by the supralinear recombination $[34,35]$. Graphene oxide-incorporated $\mathrm{CdS} / \mathrm{TiO}_{2}$ solar cell gives a short-circuit photocurrent density $\left(J_{\mathrm{SC}}\right)$ of $6.01 \mathrm{~mA} / \mathrm{cm}^{2}$ and an open-circuit voltage $\left(V_{\mathrm{OC}}\right)$ of $0.346 \mathrm{~V}$, while only $\mathrm{CdS} / \mathrm{TiO}_{2}$ solar cell reveals a $J_{\mathrm{SC}}$ of $4.4 \mathrm{~mA} / \mathrm{cm}^{2}$ and $V_{\mathrm{OC}}$ of $0.31 \mathrm{~V}$. As seen in Figs. 2 and 3 , both $J_{\mathrm{SC}}$ and $V_{\mathrm{OC}}$ values of the $\mathrm{CdS} / \mathrm{TiO}_{2}$ solar cell show an increment with the graphene oxide on the CdS surface. With the presence of graphene oxide layer, the cell efficiency was increased from about $1.42 \%$ to $2.02 \%$, and the fill factor was decreased from $1.64 \%$ to $0.31 \%$. The main drawback of these solar cells is their relatively poor fill factor. Lee and Chang [36] have reported a CdS quantum dot-sensitized solar cell that ex- 
hibited a poor fill factor in cell performance, considering the penetration of the polysulfide electrolyte in a mesoscopic $\mathrm{TiO}_{2}$ film. They indicated that the composition of the polysulfide redox electrolyte could control the value of fill factor. This means that there is a need to layer that contains hole with optimal redox couple.

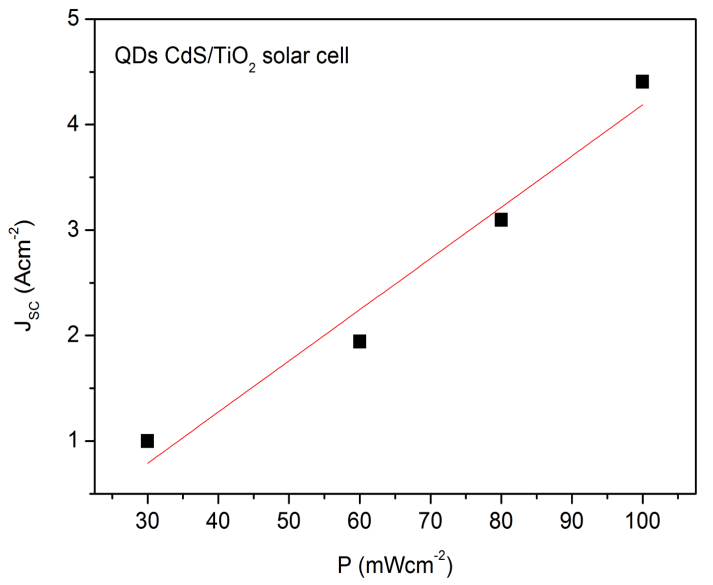

Fig. 2. Variation of $J_{\mathrm{SC}}$ vs. $P$ for $\mathrm{CdS} / \mathrm{TiO}_{2}$ solar cells.

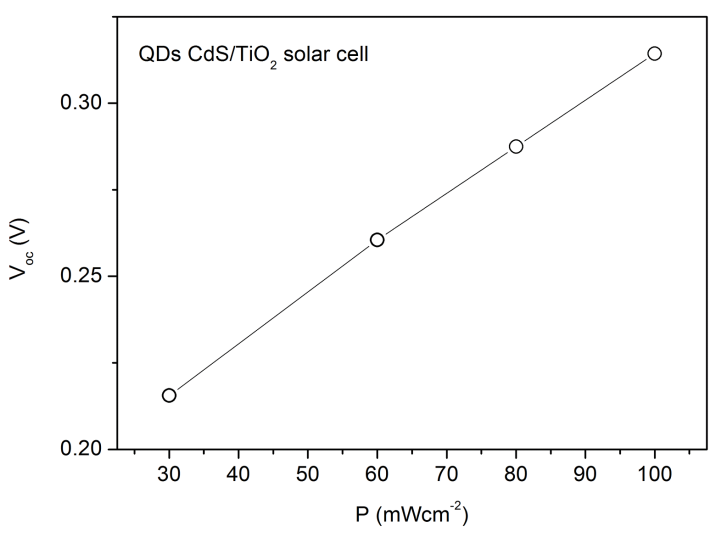

Fig. 3. Variation of $V_{\mathrm{OC}}$ vs. $P$ for $\mathrm{CdS} / \mathrm{TiO}_{2}$ solar cells.

Several factors effectively improve the performance of quantum-dot-sensitized solar cells. One of them is the counter electrode. A highly efficient quantum dot sensitized solar cell has been fabricated with ordered mesocellular carbon foam (MSU-F-C) as a counter electrode (CE). The cell with MSU-F-C CE yielded the highest power conversion efficiency of $3.60 \%$ [37]. Xu et al. [38] explored the application of $\mathrm{Cu}_{2} \mathrm{ZnSnS}_{4}$ (CZTS) microspheres as an effective counter electrode material for high-efficiency quantum dot sensitized solar cells. The cell with the CZTS microspheres presents a power conversion efficiency of $3.73 \%$.

In the present work, $\mathrm{Pt}$ deposited glass is used as a counter electrode. Pt exhibits poor electrocatalytic activity. It exhibits a lower hole-recovery rate between the counter electrode/polysulfide electrolyte interface and leads to inefficient cell performance. Efficient charge separation which provides high photocurrent density is attributed to a ZnS passivation layer before and after a $\mathrm{PbS}$ layer [39]. The charge-transfer and recombination for photogenerated charges in QDSCs depend on surface treatment [40]. Distribution of graphene oxide onto the surface of $\mathrm{CdS}$ coated $\mathrm{TiO}_{2}$ film can reduce electron-hole recombination in the interface and redirect charges, flowing back into the solar cells to produce anodic current. The electron-hole recombination is a measure of loss-rate of the power conversion efficiency for the solar cells. For example, when electrons and holes recombine, the conversion efficiency is lost in all solar cells, usually in the form of heat or light.

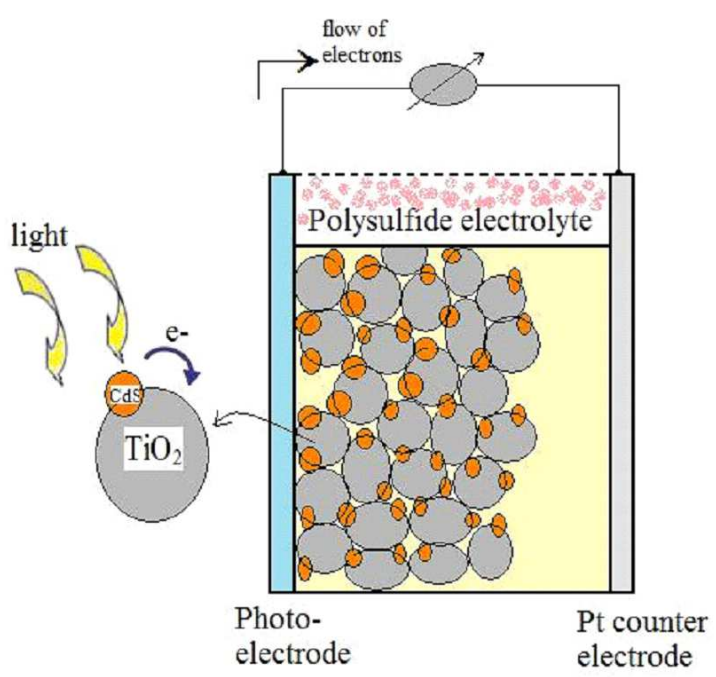

Fig. 4. Equivalent circuit of a solar cell.

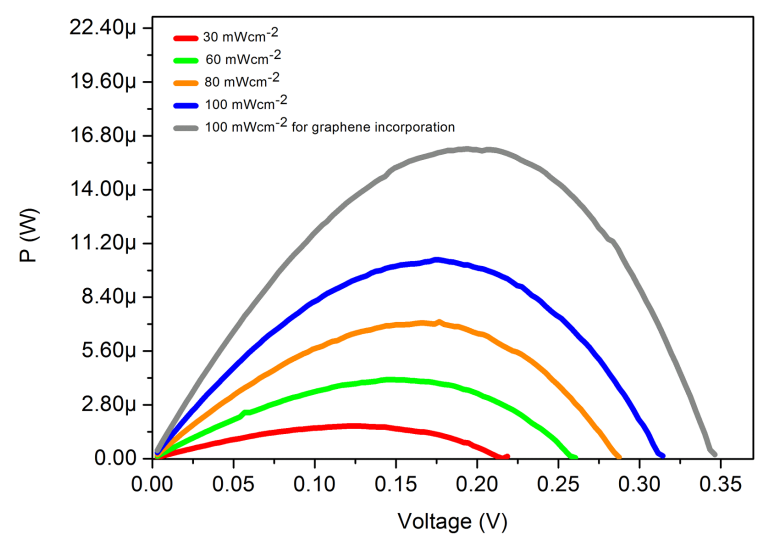

Fig. 5. Power vs. voltage plots for the fabricated solar cell at different light intensity.

The schematic structure of the prepared solar cell is shown in Fig. 4. It is possible to determine the output current of the solar cell under solar radiation with photo-induced current $\left(I_{0}=I_{\mathrm{Ph}}-I_{\mathrm{d}}\right)$. The output power of 
the solar cell is highly affected by parameters, such as sunlight intensity and direction of the cells. A solar cell responds to stimulation with incoming sunlight by transmitting a current. The power-voltage characteristics obtained using the photocurrent-voltage data of the solar cell are shown in Fig. 5. As seen in Fig. 5, the output power of the solar cell rises up to a certain voltage value and then, decreases. With increasing light intensity, the output power increases. Moreover, the output power of graphene oxide-incorporated $\mathrm{CdS} / \mathrm{TiO}_{2}$ solar cell was increased almost fifteen times compared with the solar cell without graphene oxide layer.

\subsection{Capacitance-voltage characteristics of the DSSC}

Alternating current (a.c.) characteristics of a solar cell array, especially its capacitance is important. The variations of capacitance with applied voltage at low and high frequencies for the $\mathrm{CdS} / \mathrm{TiO}_{2}$ solar cell are shown in Fig. 6. The impedance characteristics on the $\mathrm{CdS} / \mathrm{TiO}_{2}$ solar cell indicate that capacitances increase from short circuit region to $0.72 \mathrm{~V}$ at low frequency. After $30 \mathrm{kHz}$, the solar cell exhibits a negative capacitance. This behaviour can be attributed to the large current which flows through the solar cell in reverse bias. A large current observed at potentials below $0.0 \mathrm{~V}$ is assigned to a charge injection between the energy levels of $\mathrm{CdS}$ and $\mathrm{TiO}_{2}$ [41].

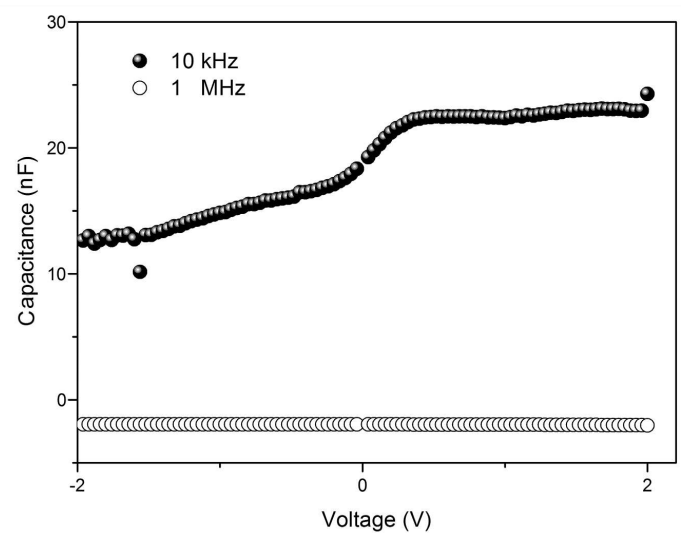

Fig. 6. Capacitance-voltage $(C-V)$ curves at different frequencies.

\section{Conclusions}

In this study, $\mathrm{TiO}_{2}$ nanopowders were prepared by solgel method. The efficiency in quantum dot sensitized graphene oxide-incorporated $\mathrm{CdS} / \mathrm{TiO}_{2}$ solar cell exhibited an increase of approximately $60 \%$ compared with sensitized by only $\mathrm{CdS} / \mathrm{TiO}_{2}$. The efficiency of $2.02 \%$ was obtained for the studied solar cell. With graphene oxide incorporation, CdS quantum dots sensitized solar cell exhibited a high photocurrent density of $6.01 \mathrm{~mA} \mathrm{~cm}^{-2}$. The obtained results suggest that the graphene oxide can be a promising material for quantum dots sensitized solar cells.

\section{Acknowledgments}

This project was funded by the Deanship of Scientific Research (DSR), King Abdulaziz University, Jeddah, under grant number: GR\# 34/4. The authors, therefore, acknowledge with thanks DSR technical and financial support.

\section{References}

[1] H. Irie, Y. Watanabe, K. Hashimoto, Chem. Lett. 32, 772 (2003).

[2] R. Asahi, T. Ohwaki, K. Aoki, Y. Taga, Science 293 , 269 (2001).

[3] H. Weng, X. Yang, J. Dong, H. Mizuseki, M. Kawasaki, Y. Kawazoe, Phys. Rev. B 69, 125219 (2004).

[4] Y. Gai, J. Li, S.S. Li, J.-B. Xia, S.-H. Wei, Phys. Rev. Lett. 102, 036402 (2009).

[5] R. Long, N.J. English, Appl. Phys. Lett. 94, 132102 (2009).

[6] A. Fujishima, K. Honda, Nature Lond. 238, 37 (1972).

[7] F.E. Osterloh, Chem. Mater. 20, 35 (2008).

[8] P.V. Kamat, J. Phys. Chem. C 111, 2834 (2007).

[9] J. Nowotny, C.C. Sorrell, T. Bak, L.R. Sheppard, Solar Energy 78, 593 (2005).

[10] K. Kalyanasundaram, M. Gratzel, Coord. Chem. Rev. 177, 347 (1998).

[11] J.B. Sambur, T. Novet, B.A. Parkinson, Science 330 , 63 (2010).

[12] B. O'Regan, M. Grätzel, Nature 353, 737 (1991).

[13] N. Zhao, T.P. Osedach, L.Y. Chang, S.M. Geyer, D. Wanger, M.T. Binda, A.C. Arango, M.G. Bawendi, V. Bulovic, ACS Nano 4, 3743 (2010).

[14] S. Gunes, K.P. Fritz, H. Neugebauer, N.S. Sariciftci, S. Kumar, G.D. Scholes, Solar Energy Mater. Solar Cells 91, 420 (2007).

[15] R. Chalita, C.R. Xiong, Jr, J.B. Kenneth, ACS Nano 2, 682 (2008).

[16] L.D. Wang, D.X. Zhao, Z.S. Su, D.Z. Shen, Nanoscale Res. Lett. 7, 106 (2012).

[17] N. Zhou, G.P. Chen, X.L. Zhang, L.Y. Cheng, Y.H. Luo, D.M. Li, Q.B. Meng, Electrochem. Comm. 20, 97 (2012).

[18] A. Braga, S. Giménez, I. Concina, A. Vomiero, I.M. Seró, Phys. Chem. Lett. 2, 454 (2011).

[19] J. Zhou, B. Song, G. Zhao, W. Dong, G. Han, Appl. Phys. A 107, 321 (2012).

[20] S.S. Mali, S.K. Desai, D.S. Dalavi, C.A. Betty, P.N. Bhosale, P.S. Patil, Photochem. Photobiol. Sci. 10, 1652 (2011).

[21] A.K. Geim, K.S. Novoselov, Nat. Mater. 6, 183 (2007).

[22] S.S. Li, K.H. Tu, C.C. Lin, M. Chhowalla, C.W. Chen, ACS Nano 4, 3169 (2010).

[23] Y. Gao, H.L. Yip, S.K. Hau, K.M. O'Malley, N.C. Cho, H.Z. Chen, A.K.Y. Jen, Appl. Phys. Lett. 97, 203306 (2010). 
[24] H. Yang, G.H. Guai, C. Guo, Q. Song, S.P. Jiang, Y. Wang, W. Zhang, C.M. Li, J. Phys. Chem. C 115, 12209 (2011).

[25] Z. Liu, J. Li, Z.-H. Sun, G. Tai, S.-P. Lau, F. Yan, ACS Nano 6, 810 (2012).

[26] S. Cheng, W. Fu, H. Yang, L. Zhang, J. Ma, H. Zhao, M. Sun, L. Yang, J. Phys. Chem. C116, 2615 (2012).

[27] W. Lee, S. Ki Min, V. Dhas, S.B. Ogale, S.-H. Han, Electrochem. Commun. 11, 103 (2009).

[28] T.A. Pham, J.S. Kim, J.S. Kim, Y.T. Jeong, Colloids Surf. A 384, 543 (2011).

[29] S.S. Malia, R.S. Devan, Y.-R. Ma, C.A. Betty, P.N. Bhosale, R.P. Panmand, B.B. Kale, S.R. Jadkar, P.S. Patil, J.-H. Kim, C.K. Hong, Electrochim. Acta 90, 666 (2013).

[30] K.S. Bindra, N. Suri, R. Thangaraj, J. Non-Cryst. Solids 353, 1446 (2007).

[31] R.K. Gupta, F. Yakuphanoglu, Solar Energy 86 , 1539 (2012)

[32] F. Yakuphanoglu, B.F. Senkal, Synth. Met. 159, 311 (2009).

[33] N. Camaioni, G. Casalbore-Miceli, G. Beggiato, M. Cristani, C. Summonte, Thin Solid Films $\mathbf{3 6 6}$, 211 (2000).
[34] R.H. Bube, Photoelectronic Properties of Semiconductors, Cambridge University Press, Cambridge 1992.

[35] F. Qasrawi, N.M. Gasanly, Solid State Commun. 141, 117 (2007).

[36] Y.L. Lee, C.H. Chang, J. Power Sources 185, 584 (2008).

[37] M. Seol, E. Ramasamy, J. Lee, K. Yong, J. Phys Chem. C 115, 22018 (2011).

[38] J. Xu, X. Yang, Q.-D. Yang, Tai-Lun Wong, C.-S. Lee, J. Phys. Chem. C 116, 19718 (2012).

[39] M.A. Hossain, Z.Y. Koh, Q. Wang, Phys. Chem. Chem. Phys. 14, 7367 (2012).

[40] E.M. Ferrero, I.M. Sero, J. Albero, S. Gimenez, J. Bisquert, E. Palomares, Phys. Chem. Chem. Phys. 12 2819 (2010).

[41] A.T. Mallajosyula, S.S.K. Iyer, B. Mazhari, Org. Electron. 13, 1158 (2012). 